\title{
CHARACTERISTIC COMPARISON OF CORNSTARCH-BASED BIOPLASTICS USING KAOLIN, MICROCRYSTALLINE CELLULOSE AND CHITOSAN AS FILLERS
}

\author{
Mai Anugrahwati*, Meilani Dwi Putri Nasution, and Febi Indah Fajarwati \\ Department of Chemistry, Faculty of Mathematics and Natural Sciences, Universitas Islam Indonesia, \\ Yogyakarta, Indonesia \\ *Email: mai.anugrahwati@uii.ac.id
}

Accepted: January 07, 2022. Approved: January 14, 2022. Published: January 17, 2022

\begin{abstract}
In the study, the basic material for making bioplastics was corn starch with the addition of kaolin, microcrystalline cellulose, and chitosan as filler variations, as well glycerol as a plasticizer. The method used was the blending method. The characterization included the absorption test for water resistance, biodegradation test, tensile and elongation strength test, and functional group analysis using FTIR. Among fillers, the best bioplastic characteristic bioplastic was obtained with filler kaolin with the water absorption value of $88.62 \%$, a tensile strength value of $1.44 \times 10^{-3} \mathrm{MPa}$, and the elongation strength value of $5.04 \%$. Nearly $80 \%$ of the material was degraded in 15 days. Spectra of FTIR showed the appearance of some functional groups from starch, filler, and plasticizer, which meant that the process of bioplastic manufacturing was physical mixing.
\end{abstract}

Keywords: Bioplastic, Corn starch, Kaolin, Microcrystalline cellulose, Chitosan, Glycerol.

\section{INTRODUCTION}

Bioplastic is plastic composed of natural polymers with properties that microbes can decompose with the help of water and oxygen [1]. Its material is one of the alternative solutions to deal with the problem of using synthetic plastics, which causes many environmental crises due to its non-degradable nature and efforts to reduce the use of petroleum as a non-renewable energy source [2], [3].

Biopolymers can be used as basic materials for making bioplastics. Its natural fibers, cellulose, polysaccharides, proteins, lipopolysaccharides, and polyhydroxyalkanoates or glycolipids. Starch (polysaccharide group) is the most widely used material because of its ability to act as a connecting matrix between fillers [2]. One of the natural resources containing starch is corn. It is a widely cultivated plant in Indonesia with 25-30\% amylose and 70-75\% amylopectin as its constituents [4].

The use of bioplastics synthesized from starch alone has low mechanical strength, so additional substances are needed to improve it. If starch is combined with a filler to form a biocomposite, the presence of this filler material will affect the properties [3]. Materials commonly used as fillers include microcrystalline cellulose, chitosan, and kaolin. Microcrystalline cellulose has been used as an environmentally friendly filler. It can strengthen biopolymers, improve mechanical properties and reduce the high-water sensitivity of bioplastic layers [5]. Chitosan is usually used as a preservative and can increase the number of hydrogen bonds in the polymer chain, where these bonds contribute to the overall strength of the bioplastic [6]. Meanwhile, kaolin also plays a role in improving the mechanical properties of bioplastics based on increasing the barrier properties of $\mathrm{CO}_{2}, \mathrm{O}_{2}$, and moisture [7].

So far, little research has been done on comparing the use of various fillers for corn starch bioplastics. Therefore, in this study, a bioplastic synthesis of corn starch with glycerol as a plasticizer was carried out and used a variety of fillers, namely microcrystalline cellulose, chitosan, and kaolin. Furthermore, the characteristics of each bioplastic will be compared.

\section{MATERIAL AND METHODS}

The research was conducted at the Laboratory of the Department of Chemistry, Faculty of Mathematics and Natural Sciences, Islamic University of Indonesia.

\section{Instruments}

This research used analytical balance, laboratory glassware, magnetic stirrer, $20 \times 20 \mathrm{~cm}$ glass mold, oven (Memmert), Tenso Lab 25087 (SALO - ITALY Type168 E), and FTIR (PerkinElmer Spectrum Version 10. 5. 1).

\section{Materials}

The materials used in this study were corn starch (Amylum maydis), distilled water, kaolin, Avicel microcrystalline cellulose $\mathrm{pH} 101$, chitosan, acetic acid 1\%, and glycerol (Merck, Germany).

\section{Methods}

\section{Synthesis of bioplastic with kaolin filler}

Corn starch with a weight of $10 \mathrm{~g}$ was dissolved in $40 \mathrm{~mL}$ of distilled water and then stirred using a stirrer for 20 minutes. At another beaker, $1 \mathrm{~g}$ of kaolin was dissolved in $60 \mathrm{~mL}$ of distilled water, then stirred for 20 minutes. After that, the two solutions were mixed, and $7 \mathrm{~mL}$ of glycerol was added, then heated at $70{ }^{\circ} \mathrm{C}$ for 30 minutes while stirring. Furthermore, the solution was thoroughly mixed, poured into a glass mold $\left(20 \times 20 \mathrm{~cm}^{2}\right)$, and dried in an oven at $50{ }^{\circ} \mathrm{C}$ for 5 hours. After cold, it was released from the glass mold. 


\section{Synthesis of bioplastic with chitosan filler}

$10 \mathrm{~g}$ of corn starch was dissolved in $40 \mathrm{~mL}$ of distilled water, then was stirred using for 20 minutes. $1 \mathrm{~g}$ of microcrystalline cellulose was dissolved in $60 \mathrm{~mL}$ of distilled water, then was stirred using for 20 minutes. After that, the two solutions were mixed, and $7 \mathrm{~mL}$ of glycerol was added, then heated at $70{ }^{\circ} \mathrm{C}$ for 30 minutes while stirring. Furthermore, the solution was mixed perfectly, poured into a glass mold $\left(20 \times 20 \mathrm{~cm}^{2}\right)$, and was dried in an oven at a temperature of $50{ }^{\circ} \mathrm{C}$ for 5 hours. After cold, it was released from the glass mold.

\section{Synthesis of bioplastic with microcrystalline cellulose filler}

$10 \mathrm{~g}$ of corn starch was dissolved in $40 \mathrm{~mL}$ of distilled water, then was stirred for 20 minutes. $1 \mathrm{~g}$ of chitosan was dissolved in $60 \mathrm{~mL}$ of $1 \%$ acetic acid, then stirred for 20 minutes. After that, the two solutions were mixed, $7 \mathrm{~mL}$ of glycerol was added, and heated at $70{ }^{\circ} \mathrm{C}$ for 30 minutes while stirring. Furthermore, the solution was mixed perfectly, poured into a mold $\left(20 \times 20 \mathrm{~cm}^{2}\right)$, and dried in an oven at a temperature of $50{ }^{\circ} \mathrm{C}$ for 5 hours. After cold, it was released from the glass mold.

\section{Characterization}

\section{Functional group analysis}

Chemical characterization of the resulting bioplastics was carried out by functional group analysis using Attenuated Total Reflectance (ATR) FTIR spectroscopy. From the IR spectra, functional groups presence in the three bioplastics were compared.

\section{Tensile strength and elongation at break tests}

The computer and the Tenso Lab were connected to a power source. Then the computer that already has the software and the connected Tenso Lab was turned on. The bioplastic sample was cut to a size of $2.5 \mathrm{~cm} \mathrm{x} 20 \mathrm{~cm}$, then the material to be tested was clamped between two clamps in the Tenso Lab place, after which the tensile strength and elongation values will appear on the monitor until the material breaks automatically.

\section{Water absorption test}

Each bioplastic sample was cut to a size of 3 $\mathrm{x} 3 \mathrm{~cm}^{2}$. Then the sample was placed in a desiccator for 15 minutes. After that, the initial weight of the sample $\left(\mathrm{M}_{\mathrm{o}}\right)$ was observed, then immersed in water for 20 seconds. Then the sample was dried using a dry tissue, and its final weight $\left(\mathrm{M}_{1}\right)$ was weight. The process was repeated to get constant weight.

Weight increase $(\%)=\frac{M_{1}-M_{0}}{M_{1}} \times 100 \%$

Water endurance $=100 \%$ - weight increase $(\%)$

Description

$\mathrm{M}_{1}=$ final weight $(\mathrm{g})$
$\mathrm{M}_{0}=$ initial weight $(\mathrm{g})$

\section{Biodegradation test}

The biodegradation test was carried out by planting the bioplastic samples into the soil with $5 \mathrm{~cm}$ in depth from the soil surface for 15 days and then calculating the percent reduction in weight.

Reduction in weight $(\%)=\frac{w_{1}-w_{2}}{w_{1}} \times 100 \%$

Description :

$\mathrm{w}_{1}=$ weight of sample before biodegradation $(\mathrm{g})$

$\mathrm{w}_{2}=$ weight of sample after biodegradation $(\mathrm{g})$

\section{RESULTS AND DISCUSSION}

The manufacture of bioplastics in this research was carried out using the blending method. Its method is a method of mixing two or more materials into one with the advantage of not using a lot of raw materials, requiring less time and affordable costs [8]. The raw materials used in the manufacture of bioplastics here were corn starch, glycerol, various fillers in the form of kaolin, microcrystalline cellulose, and chitosan with the ratio of weight from starch: glycerol:filler was 10:7:1. In this case, glycerol functions as a plasticizer that lubricates bioplastics [9].

One of the causes of bioplastic flexibility is glycerol which can weaken polymer strength while increasing flexibility and extensibility [3]. The hydroxyl group in glycerol plays a role in inter and intramolecular interactions (hydrogen bonds) in the polymer chain to produce a bioplastic layer with a flexible structure [10]. In addition, glycerol has hydrophilic properties, is easily degraded, cheap, and easy to obtain.

The temperature of bioplastics synthesis was also a concern because temperature regulation aimed to form gelatinized starch as the initial formation of bioplastics. The heating temperature determines the degree of gelatinization that usually occurs at a temperature of $70^{\circ} \mathrm{C}$ and the physical properties of the bioplastic formed [10]. This heating temperature must be really maintained, not too high or too low, because both will cause damage to the starch.

From the study (Figure 1.), it could be seen that the bioplastic with kaolin filler was brownishwhite, stiff, hard, had a smooth surface, and was rather difficult to remove from the mold after drying. Bioplastic with microcrystalline cellulose filler was clear white, stiff, slightly hard, had a smooth surface, and was easily removed from the mold after drying. Meanwhile, bioplastic with chitosan filler was yellowish, stiff, hard, had a smooth surface, and was less easy to remove from the mold after drying. 


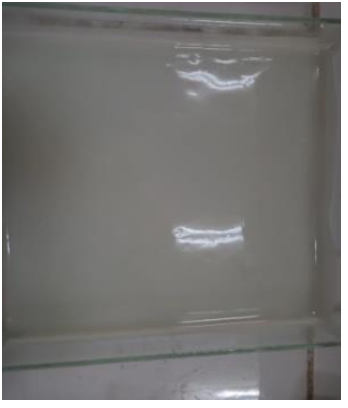

a

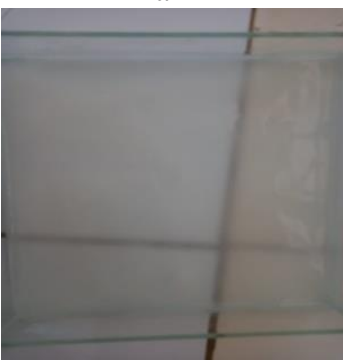

c

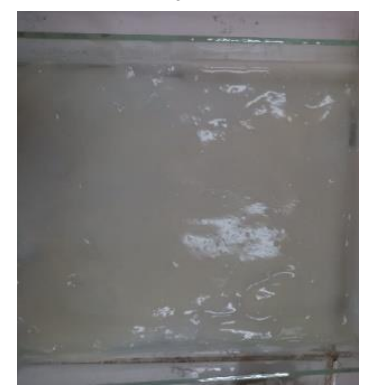

e

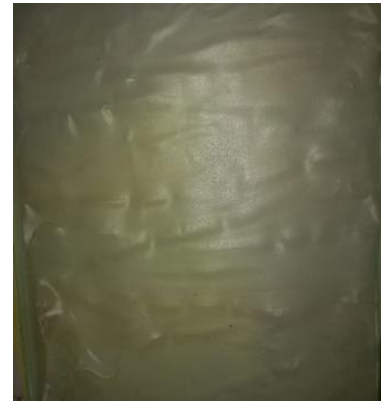

b

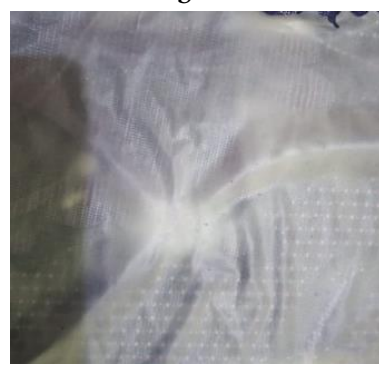

d

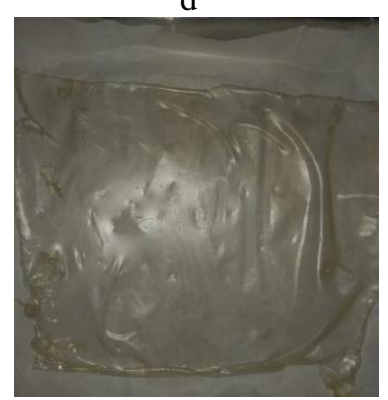

f
Figure 1. Bioplastic with kaolin filler (a) during molding and (b) after drying, microcrystalline cellulose filler (c) during molding (d) after drying, chitosan filler (e) during molding, and (f) after drying.

\section{FTIR Characterization}

The ATR-FTIR analysis was carried out to identify the presence of functional groups contained in the bioplastic by looking at the absorption peaks that appeared in the IR spectra. This analysis was conducted to determine the functional groups of the constituents of corn starch and various filler, namely kaolin, microcrystalline cellulose, and chitosan.

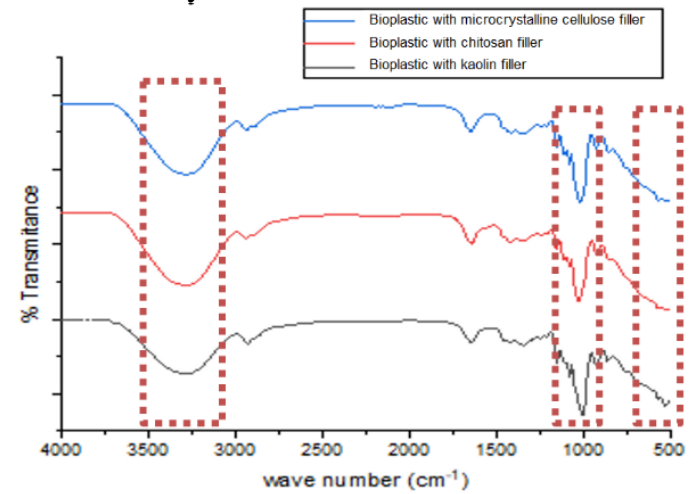

Figure 2. Results of FTIR spectra of bioplastics with various fillers
In Figure 2. it can be seen the dominant absorption band of starch as a bioplastic raw material with three variations of filler. The spectrum IR of bioplastic is $\mathrm{O}-\mathrm{H}$ bond stretching at $3200-3500 \mathrm{~cm}^{-1}$, $\mathrm{C}-\mathrm{H}$ bond stretching around $2900 \mathrm{~cm}^{-1}$, C-O functional group at the of $1600 \mathrm{~cm}^{-1}$ is associated with the $\mathrm{O}-\mathrm{H}$ group, the $\mathrm{C}-\mathrm{O}-\mathrm{C}$ group in the absorption band around $1100 \mathrm{~cm}^{-1}$, and stretching $\mathrm{C}-\mathrm{O}$ at 990 $1010 \mathrm{~cm}^{-1}$. The characteristic absorption band of starch is at wavenumbers between $700-900 \mathrm{~cm}^{-1}$ which showed the C-O-C vibration of the carbohydrate ring [11].

These three spectra look almost identical because the corn starch is more dominant than the filler. Starch and microcrystalline cellulose have quite similar functional groups. Therefore, the adsorption band was assumed to be identical to one in the bioplastic with microcrystalline cellulose filler. No different absorption peaks were found in the bioplastic with chitosan filler because several absorptions of other functional groups overlap, such as $\mathrm{O}-\mathrm{H}$ and $\mathrm{N}$ $\mathrm{H}$ at wavenumbers 3200-3500 cm-1[12]. In comparison, the bioplastic spectra with kaolin filler have differences in the appearance of absorption at a wavenumber of about $530 \mathrm{~cm}^{-1}$ that showed the presence of the $\mathrm{Si}-\mathrm{O}-\mathrm{Al}$ group. An increase in absorption intensity at a wavenumber of $1000 \mathrm{~cm}^{-1}$ indicates the presence of the $\mathrm{Al} / \mathrm{Si}$ phase in starch polymers and a slight reduction in $\mathrm{O}-\mathrm{H}$ absorption intensity which shows the hydrophobic effect of kaolin in bioplastics [7].

From the three spectrums in Figure 2., in general, these bioplastics contain hydroxy $(\mathrm{O}-\mathrm{H})$, carbonyl $(\mathrm{C}=\mathrm{O})$, carboxyl $(\mathrm{C}-\mathrm{O})$, and $\mathrm{C}-\mathrm{H}$ aromatic groups. Its means that these functional groups can bind with other compounds to form branched chain bonds and cross-linking so that it is possible to produce a strong polymer. Chemical solid bonds depend on the number of molecular bonds and the type of bonds, such as hydrogen bonds which occurred due to the interaction between $\mathrm{O}$ with $\mathrm{H}$ and $\mathrm{N}$ with $\mathrm{H}$ among starch molecules, glycerol, and fillers in these bioplastics. The higher number of bonds among molecules, the stronger the resulting material. The presence of $\mathrm{O}-\mathrm{H}$ and $\mathrm{C}-\mathrm{O}$ groups also causes bioplastics to be degraded by nature easily. The spectrum results show that there is no emergence of new functional groups, which means that the process of bioplastic synthesis in this study was categorized as physical mixing [12].

\section{Tensile strength and elongation at break tests}

This tensile strength test determines the magnitude of the tensile force required to achieve maximum tensile strength before the bioplastic breaks. The mechanical properties are influenced by the amount of content of the components that make up a bioplastic. The higher the tensile strength value of a bioplastic, the better the bioplastic produced to protect it from mechanical disturbances such as friction or collision. There is also elongation at break test, in 
which elongation is a value that shows the increase in length of a material when a tensile force is applied until the material breaks.

In this study, both mechanical property tests were carried out at the Textile Evaluation Lab of the Islamic University of Indonesia. The results of testing the mechanical properties can be seen in Table 1 .

Table 1. Test Results of the Mechanical Properties of Bioplastics

\begin{tabular}{ccc}
\hline \multirow{2}{*}{ Bioplastics } & \multicolumn{2}{c}{ Values } \\
\cline { 2 - 3 } & $\begin{array}{c}\text { Tensile } \\
\text { strength } \\
(\mathrm{MPa})\end{array}$ & $\begin{array}{c}\text { Elongation at } \\
\text { break } \\
(\%)\end{array}$ \\
\hline Starch + Kaolin & $1.569 \times 10^{-3}$ & 7.533 \\
& $1.373 \times 10^{-3}$ & 4.266 \\
Average & $1.373 \times 10^{-3}$ & 3.333 \\
Starch + & $1.438 \times 10^{-3}$ & 5.044 \\
chitosan & $1.373 \times 10^{-3}$ & 37.333 \\
& $1.117 \times 10^{-3}$ & 37.600 \\
Average & $1.242 \times 10^{-3}$ & 32.000 \\
Starch + & $5.886 \times 10^{-3}$ & 35.644 \\
microcrystalline & $5.886 \times 10^{-4}$ & 8.800 \\
cellulose & $9.810 \times 10^{-4}$ & 9.400 \\
Average & $4.251 \times 10^{-4}$ & 13.200 \\
\hline
\end{tabular}

Table 1. shows that the addition of different fillers had different effects on the tensile strength results due to the other content of the components that composed the filler that was used in the manufacture of bioplastics. The highest tensile strength value was $1.44 \times 10^{-3} \mathrm{MPa}$ in bioplastic with the addition of kaolin filler because hydrogen bonds in the matrix increased with the addition of kaolin [13]. This hydrogen bond occurs when the $\mathrm{O}$ atoms in kaolin interact with $\mathrm{H}$ atoms in amylose, causing the bioplastic to become stronger. In bioplastic with chitosan filler, the tensile strength value was $1.242 \mathrm{x}$ $10^{-3} \mathrm{MPa}$. The addition of chitosan will decrease the tensile strength of a bioplastic. Chitosan has a linear polymer chain structure that forms a crystalline phase because it can arrange regular polymer molecules. This crystalline phase provided strength, stiffness, and hardness so that it caused bioplastics to break more efficiently [14].

Microcrystalline cellulose filler had the lowest tensile strength value of $4.251 \times 10^{-4} \mathrm{MPa}$. The addition of kaolin filler provided the highest tensile test value compared to other fillers. The interaction between kaolin and starch increases the overall crystallinity of the system and increases the value of tensile strength [15]. Based on the analysis results with Anova, it is known that the addition of filler variations has a significant effect $(p<0.05)$ on the tensile strength test value of the bioplastics.

The factor that affects the value of the tensile strength of bioplastic is the affinity between its constituent components. Affinity is a phenomenon where specific molecules tend to unite and bond. As the affinity increases, the bonds between molecules will also increase. The chemical bonds of its constituents influence the strength of a material. The power of a chemical bond depends on the number of molecular bonds and the type of bond. Strong chemical bonds will be difficult to break, so it takes a lot of energy to break these bonds [4].

From Table 1. it can be seen that the highest elongation value is $35.64 \%$ from bioplastic with the addition of chitosan filler. The addition of microcrystalline cellulose filler obtained an elongation value of $10.47 \%$. In comparison, the addition of kaolin filler received an elongation value of $5.04 \%$. It could be concluded that the addition of chitosan filler produces bioplastics with the largest elongation compared to other fillers in this study. Chitosan has amine functional groups, primary and secondary hydroxyl groups, causing high chemical reactivity in starch suspensions and hydrogen bonding interactions between starch and chitosan resulting in bioplastics with improved mechanical properties [16] compared to kaolin fillers and microcrystalline cellulose. Based on the results of the Anova test, it was seen that the addition of various filler had a significant effect $(p<0.05)$ on the elongation value of these bioplastics.

In general, the elongation value in bioplastic is also influenced by glycerol as a plasticizer that provides elastic properties to the bioplastic film. Previous research stated that glycerol increased the elongation value but decreased the tensile strength value in bioplastics [14]. Glycerol as a plasticizer would be located between the biopolymer chains. The distance between the filler and starch will increase reduce the hydrogen bonding between filler-starch and hydrogen interactions between filler-glycerol and glycerol-starch replaced it. Thus the bioplastic will be more elastic.

\section{Water adsorption test}

The results of the water absorption test for all bioplastics with various fillers can be seen in Table 2 .

Table 2. Results of Water Absorption Test and Bioplastic Resistance

\begin{tabular}{|c|c|c|c|c|c|}
\hline \multirow{2}{*}{ No } & \multirow{2}{*}{ Bioplastics } & \multicolumn{2}{|c|}{ Weight $(\mathrm{g})$} & \multirow{2}{*}{$\begin{array}{c}\text { Weight } \\
\text { increase } \\
(\%)\end{array}$} & \multirow{2}{*}{$\begin{array}{c}\text { Water- } \\
\text { resistance } \\
(\%)\end{array}$} \\
\hline & & Initial & Final & & \\
\hline \multirow{4}{*}{1} & \multirow{3}{*}{$\begin{array}{c}\text { Starch + } \\
\text { kaolin }\end{array}$} & 0.4752 & 0.5390 & 11.918 & 88.081 \\
\hline & & 0.4858 & 0.5429 & 10.517 & 89.483 \\
\hline & & 0.4779 & 0.5419 & 11.810 & 88.190 \\
\hline & Rata-rata & & & 11.415 & 88.585 \\
\hline \multirow{3}{*}{2} & \multirow{3}{*}{$\begin{array}{l}\text { Starch + } \\
\text { chitosan }\end{array}$} & 0.4351 & 0.4818 & 9.6928 & 90.308 \\
\hline & & 0.4202 & 0.4848 & 13.325 & 86.675 \\
\hline & & 0.4316 & 0.4948 & 12.772 & 87.228 \\
\hline \multirow{5}{*}{3} & Rata-rata & & & 11.929 & 88.070 \\
\hline & Starch + & 0.5051 & 0.5969 & 15.379 & 84.620 \\
\hline & selulosa & 0.4856 & 0.5778 & 15.957 & 84.042 \\
\hline & micochitosan & 0.5362 & 0.6591 & 18.646 & 81.353 \\
\hline & Rata-rata & & & 16.661 & 83.338 \\
\hline
\end{tabular}


From Table 2, it could be seen that the values of weight increase and bioplastic water-resistance are different. Bioplastic with microcrystalline cellulose filler had the lowest water resistance value, namely $83.44 \%$. Microcrystalline cellulose is hydrophilic, so it binds to water [3]. Bioplastic with chitosan had a higher water resistance value of $88.07 \%$ because chitosan is hydrophobic and may reduce moisture in bioplastics. As for the bioplastic with kaolin, the water-resistance value is $88.62 \%$ because kaolin binds to the hydrophilic group present in starch-glycerol so that the absorption to water is reduced [13]. Based on the results of the Anova test, it showed that the addition of different fillers had a very significant effect $(p<0.05)$ on the water resistance of bioplastics.

The water absorption test is one of the important parameters for the properties of bioplastics, where the higher the water absorption capacity of a bioplastic, the lower the level of bioplastic resistance to water so that the bioplastic films produced is more likely to damage. Likewise, suppose the absorption rate is low. In that case, the level of bioplastic resistance will be more significant in water to slow down the damage and prolong the bioplastic lifetime.

\section{Biodegradation test}

A biodegradation test was carried out to determine how many bioplastics were decomposed by soil microorganisms. The results of the observations of this bioplastic biodegradation test are available in Table 3 .

Table 3. Observation Results of Bioplastic Biodegradation Test

\begin{tabular}{ccccc}
\hline \multirow{2}{*}{ Day } & $\begin{array}{c}\text { Bioplastic with } \\
\text { filler }\end{array}$ & $\begin{array}{c}\mathrm{W}_{1} \\
(\mathrm{~g})\end{array}$ & $\begin{array}{c}\mathrm{W}_{2} \\
(\mathrm{~g})\end{array}$ & $\begin{array}{c}\text { Weight } \\
\text { reduction } \\
(\%)\end{array}$ \\
\hline \multirow{4}{*}{5} & $\begin{array}{c}\text { Microcrystalline } \\
\text { cellulose }\end{array}$ & 0.694 & 0.449 & 35.302 \\
& $\begin{array}{c}\text { Chitosan } \\
\text { Kaolin }\end{array}$ & 0.691 & 0.441 & 36.179 \\
\cline { 2 - 5 } 10 & $\begin{array}{c}\text { Kicrocrystalline } \\
\text { cellulose }\end{array}$ & 0.694 & 0.221 & 68.155 \\
& Chitosan & 0.691 & 0.319 & 53.835 \\
\cline { 2 - 5 } 15 & Kaolin & 0.694 & 0.119 & 88.597 \\
\cline { 2 - 5 } & Microcrystalline & 0.718 & 0.198 & 72.610 \\
& $\begin{array}{c}\text { cellulose } \\
\text { Chitosan }\end{array}$ & 0.691 & 0.123 & 82.199 \\
\hline
\end{tabular}

Based on Table 3. it can be seen that on the $15^{\text {th }}$ day, bioplastics with microcrystalline cellulose filler had the lowest percent weight reduction, which was $72.61 \%$, compared to the other two fillers. Cellulose is a natural material that can be degraded in nature due to microbial activity in the soil. Polymers of cellulose and starch, which have O-H groups, will decompose into small pieces until they disappear in the soil. The polymer will be degraded to damage or a decrease in quality to break the polymer's chain bonds [17].
In bioplastics with kaolin filler, the largest percentage reduction is $88.59 \%$ on the $15^{\text {th }}$ day because microorganisms quickly degrade kaolin. Likewise, bioplastic with chitosan is easily degraded by microorganisms because it is a polysaccharide element, and the percentage reduction in weight is $82.20 \%$.

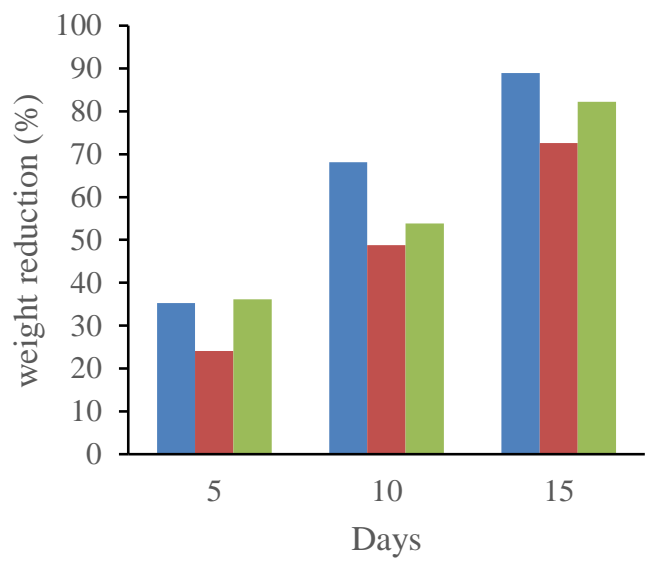

- Kaolin Microcrystalline cellulose $\quad$ Chitosan

Figure 3. Bioplastic Weight Reduction Test Results

Figure 3. also shows the relationship between burial time in days and the percent reduction in the weight of the degraded sample. The longer the burial time, the greater the percent weight reduction of the sample. The results obtained in this study, bioplastics with various fillers have reached $70-80 \%$ degradation on day 15 , which means that these bioplastics have complied with the standard for biodegradable plastics, which must decompose in less than 180 days (ASTM D 6400 and EN 13432) [13]. Based on the Anova test, the difference in filler has a significant effect $(p<0.05)$ on the bioplastic biodegradability properties formed.

\section{CONCLUSION}

Based on this research, it could be concluded that the addition of different fillers (kaolin, microcrystalline cellulose, and chitosan) in bioplastics from corn starch and glycerol as a plasticizer. The same mass ratio significantly affects the bioplastic characters, such as tensile strength, elongation, water absorption, and biodegradable properties. Only the elongation at break results from bioplastic with chitosan filler and biodegradation test results from all bioplastics were in accordance with the applicable bioplastic quality standard criteria such as Indonesian National Standard (SNI) and ASTM D6400. Therefore, further research is still needed to optimize the character of these bioplastics.

\section{REFERENCES}

[1] Atiwesh, G., Mikhael, A., Parrish, C. C., Banoub, J., and Le., T.-A. T. (2021). Environmental impact of bioplastic use: A review. Heliyon, 7 (9), $1-9$ 
[2] Abotbina, W., Sapuan, S. M., Sultan, M. T. H., Alkbir, M. F. M., and Ilyas, R. A. (2021). Development and characterization of cornstarchbased bioplastics packaging film using a combination of different plasticizers. Polymers, 13 (20), 1-18

[3] Darni, Y., Dewi, F. Y., and Lismeri, L. (2017). Modification of Sorghum Starch-Cellulose Bioplastic with Sorghum Stalks Filler. Jurnal Rekayasa Kimia \& Lingkungan, 12 (1), 22-30

[4] Putra, A. D. , Amri, I., and Irdoni. (2019). Sintesis Bioplastik Berbahan Dasar Pati Jagung dengan Penambahan Filler Selulosa Serat Daun Nanas (Ananas cosmosus). JOM FTEKNIK, 6 (1), 1-8.

[5] Chen, J., Long, Z., Dou, C., Wang, X., and Meng, Y. (2021). Processing and characterization of thermoplastic corn starch-based film/paper composites containing microcrystalline cellulose. Journal of the Science of Food and Agriculture, 101 (15), 6443-6451.

[6] Amalia, D., Saleh, D., and Djonaedi, E. (2020). Synthesis of biodegradable plastics using corn starch and corn husk as the fillers as well as chitosan and sorbitol. Journal of Physics: Conference Series, 1442 (1), 1-7.

[7] Mohan, T. P., Devchand, K., and Kanny, K. (2017). Barrier and biodegradable properties of corn starch-derived biopolymer film filled with nanoclay fillers. Journal of Plastic Film and Sheeting, 33 (3), 309-336.

[8] Syuhada, M., Sofa, S. A., and Sedyadi, E. (2020). The Effect of Cassava Peel Starch Addition to Bioplastic Biodegradation Based on Chitosan on Soil and River Water Media. Biology, Medicine, \& Natural Product Chemistry, 9 (1), 7-13.

[9] Reyes, J. D. C., Tungol, J. M., Musngi, P. P., Magarro, A. S., Guevarra, K. F., and Santos, J. S. (2020). Three Experimental Phases of Cornstarch-Based Biodegradable Plastic. Journal of Humanities and Education Development, 2 (2), 81-89.

[10] Souza, A. C., Benze, R., Ferrão, E. S., Ditchfield, C., Coelho, A. C. V., and Tadini, C. C. (2012). Cassava starch biodegradable films: Influence of glycerol and clay nanoparticles content on tensile and barrier properties and glass transition temperature. LWT - Food Science and Technology, 46 (1), 110-117.

[11] Abdullah, A. H. D., Chalimah, S., Primadona, I., and Hanantyo, M. H. G. (2018). Physical and chemical properties of corn, cassava, and potato starch. IOP Conference Series: Earth and Environmental Science, 160 (1), 1-6.

[12] Syuhada, M., Sofa, S. A., and Sedyadi, E. (2020). The Effect of Cassava Peel Starch Addition to Bioplastic Biodegradation Based on Chitosan on Soil and River Water Media. Biology, Medicine, \& Natural Product Chemistry, 9 (1), 7-13.
[13] Sunardi, S., Susanti, Y., and Mustikasari, K. (2020). Sintesis Dan Karakterisasi Bioplastik Dari Pati Ubi Nagara Dengan Kaolin Sebagai Penguat. Jurnal Riset Industri Hasil Hutan, 11 (2), 65-76.

[14] Elly Agustin, Y., Samuel Padmawijaya, K. and Kunci, K. (2016). Sintesis Bioplastik Dari Kitosan-Pati Kulit Pisang Kepok Dengan Penambahan Zat Aditif. Jurnal Teknik Kimia, 10 (2), 2-16.

[15] Ashaduzzaman, M., Saha, D., and Rashid, M. M. (2020). Mechanical and thermal properties of self-assembled kaolin-doped starch-based environment-friendly nanocomposite films. Journal of Composites Science, 4 (38), 1-14.

[16] Ginting, M. H. S., Lubis, M., Sidabutar, T., and Sirait, T. P. (2018). The effect of increasing chitosan on the characteristics of bioplastic from starch talas (Colocasia esculenta) using plasticizer sorbitol. IOP Conference Series: Earth and Environmental Science, 126 (1), 1-7.

[17] Oktaviani, C., Khairat, and Bahruddin. (2019). Modifikasi Bioplastik Berbasis Pati Sagu Dengan Asam Sitrat Dan Filler Microcrystalline Cellulose (MCC). JOM FTEKNIK, 6 (1), 1-5. 